Didaché: Journal of Christian Education

Vol. 2, No. 1 (2021): 20-42

e-ISSN: 2722-8584

Published by: Sekolah Tinggi Teologi Simpson Ungaran

DOI: $10.46445 /$ djce.v2i1.386

\title{
Korupsi dalam Sorotan Etika Kristen dan Implikasinya Bagi Pendidikan Anti Korupsi
}

\author{
Sostenis Nggebu \\ Sekolah Tinggi Teologi Saint Paul Bandung \\ email: sostenis.nggebu@gmail.com
}

\begin{abstract}
This article addresses the problem of corruption in Christian ethics based on the reference of God's word. Christians involved in corruption show that carrying out governmental duties is outside the control of God's word. To examine this topic more deeply, the author uses descriptive methods and literature studies. The results and conclusions of this study show that the corruptors prioritize the works of the flesh, worship material things, give in to worldly temptations, violate Christian morality, and do not glorify God in their lives. Those corrupt Christian bureaucrats who are dominated by greed and greed are not the characters expected by God, and by doing so, they lose the opportunity to be witnesses of Christ in the world. Corruption is bad behavior, so there is an opportunity for the church to pay attention to anti-corruption education for the congregation so that those who sit in government can carry out their duties and responsibilities by the demands of the Christian faith.
\end{abstract}

Keywords: corruption, Christian ethics, education

\begin{abstract}
Abstrak
Artikel ini menyoroti permasalahan korupsi secara etika Kristen berdasarkan acuan firman Tuhan. Untuk mengkaji topik ini lebih mendalam, penulis menggunakan metode deskriptif dan studi literatur. Hasil dan kesimpulan dari studi ini menunjukkan bahwa para koruptor mengutamakan perbuatan daging, mendewakan materi, menyerah pada godaan keduniawian, melanggar moralitas Kristen dan tidak memuliakan Allah di dalam hidup mereka. Para birokrat Kristen yang korup itu dikuasai oleh sifat serakah dan tamak bukanlah karakter yang diharapkan oleh Tuhan dan dengan berbuat seperti itu mereka kehilangan kesempatan menjadi saksi Kristus di tengah dunia. Korupsi itu sebagai perilaku yang buruk maka terbuka peluang bagi gereja untuk memperhatikan pendidikan anti korupsi bagi jemaat agar mereka yang duduk dalam pemerintahan dapat menjalankan tugas dan tanggung jawabnya sesuai dengan tuntutan iman Kristen.
\end{abstract}

Kata kunci: korupsi, etika Kristen, pendidikan

$\begin{array}{llll}\text { Article History } & \text { Received: March 17, } 2021 \quad \text { Revised: May 10, } 2021 \quad \text { Accepted: May 25, } 2021\end{array}$

This is an open access article under the CC BY-SA license 


\section{Pendahuluan}

Secara historis korupsi merupakan permasalahan etika yang dihadapi oleh seluruh umat manusia sejak ribuan tahun yang lalu hingga saat ini. Handayani (2019, p. 4) mengategorikan Hofni dan Pinehas telah berbuat curang dengan mengambil kurban persembahan yang merupakan hak Tuhan. Sifat curang itu dapat memenuhi kriteria korupsi. Demikian juga jika dilihat dari konteks kekinian, kasus korupsi tetap marak akhir-akhir ini. Kasus korupsi pada akhir tahun 2020 yang lalu menarik perhatian masyarakat Indonesia yang dilakukan oleh mantan Menteri Sosial Juliari Batubara yang menerima suap dari pihak ketiga dalam program bantuan sosial dari dampak Covid-19. Secara etika Kristen, ia tergolong pejabat Kristen yang mudah tergoda dengan harta duniawi yang sekaligus meruntuhkan moralitasnya. Dari data ini, memunculkan problema moral dalam diri koruptor yang patut disoroti secara etika Kristen. Korupsi sebagai tindakan yang bertentangan dengan kebenaran firman Allah, dikuasai keserakahan, bersifat tamak, membohongi hati nurani dan abaikan dalam tanggung jawab pribadi sebagai orang percaya. Masalah korupsi bukan saja menciderai hukum negara (bersifat yuridis) tetapi juga bertentangan dengan kebenaran absolut (bersifat moralitas yang secara khusus berurusan dengan etika Kristen dan firman Allah). Pada dasarnya korupsi sebagai kejahatan yang bertentangan dengan iman Kristen dan kesaksian Alkitab. Tindak korupsi itu dilatarbelakangi oleh motif dan tujuan tertentu yang bertentangan dengan kebenaran Alkitab.

Kajian tentang korupsi yang ditinjau secara etika Kristen telah mendapat perhatian dari para peneliti masa kini. Handayani (2019, pp. 1-8) memandang korupsi sudah berakar dalam sejarah kuno sejak zaman Mesopotamia yang menjalar hingga dewasa ini. Pada masa itu, korupsi kerap kali dikaitkan dengan politeisme dari bangsa-bangsa di sekitar Israel yang berdampak buruk bagi umat Tuhan. Kemudian, Dewantara (2018, p. 38) menggali jiwa anti-korupsi secara iman Kristen yang dikaitkan dengan dialog antaragama. Beliau menekankan tentang pentingnya sikap kebaikan yang selaras dengan cita-cita bangsa yang berkarakter religius. Selanjutnya, Dharmawan (2019, p. 38) memaparkan tentang penerapan etika Kristen bagi akuntan dalam upaya pemberantasan korupsi. Pembahasan beliau dikaitkan dengan tugas seorang akuntan yang berada di garis depan agar turut serta dalam mengatasi korupsi. Kaparang dan Siburian (2021, pp. 60-61) menelisik isu suap dari sudut refleksi apologetis etis. Keduanya menyimpulkan bahwa orang Kristen dalam menggunakan uang mesti berpe- 
doman pada refleksi etis bahwa uang itu bersumber dari Allah, oleh Allah dan bagi atau untuk kepentingan dalam Allah. Dalam penggunaannya orang Kristen berpedoman pada konteks keabsolutan dari Allah sendiri. Sehingga, memberi suap itu bertentangan dengan citra Allah sendiri.

Setelah menyimak pembahasan yang dikemukakan oleh para peneliti di atas, penulis melihat pentingnya menyoroti korupsi secara etika Kristen melalui rujukan firman Allah sebagai kebenaran absolut untuk menyoroti isu korupsi di Indonesia. Orang Kristen dipanggil Allah dan ditempatkan untuk berkarya dalam pemerintahan seyogianya memelihara citranya sebagai orang yang takut akan Allah dengan melakukan kebenaran dan keadilan dengan sepenuh hati di tengah masyarakat luas, bukannya berbuat curang sementara menjalankan tugasnya. Maka topik itu menjadi fokus penelitian dalam artikel ini. Mengapa korupsi termasuk pelanggaran terhadap firman Allah? Apa faktor pendorong terjadinya tindak korupsi itu? Bagaimana menilai korupsi dari sudut pandang etika Kristen? Dan, selanjutnya penulis mengajukan gagasan tentang pentingnya pendidikan anti korupsi bagi generasi muda atau warga gereja. Pendidikan anti korupsi bagi warga gereja sebagai sarana efektif untuk mempersiapkan mereka menjalankan roda pemerintahan dalam kontrol firman Allah.

\section{Metode}

Dalam pembahasan paper ini, penulis menggunakan metode deskriptif. Sukmadinata (2017, p. 72) mengatakan metode deskriptif digunakan untuk meneliti fenomena yang muncul di tengah masyarakat yang dikaitkan dengan perbuatan manusia yang mencakup aktivitasnya, karakteristiknya dan hubungan antar fenomena yang satu dengan yang lainnya. Fenomena yang dimaksud dalam penelitian ini adalah kasus korupsi yang disoroti secara etika Kristen.

Selain itu, digunakan juga studi literatur. Menurut Nasir (2014, pp. 111112), studi literatur digunakan untuk menelusuri dan menelaah materi dalam pustaka yang telah ada yang dikaitkan dengan masalah korupsi. Studi semacam ini ditempuh guna memperoleh data terbaru guna merumuskan ide penelitian. Secara khusus dalam kajian ini, penulis menggunakan hasil penelitian terkini yang dilakukan oleh Dharmawan (2019) tentang pentingnya pehadiran akuntan yang beretika. Juga digunakan padangan Hasibuan (2017) tentang politikus yang beretika; dan kajian dari Dewantara (2018) mengajukan pentingnya penerapan etika dalam dialog guna pemberantasan korupsi. Selain hasil penelitian, digunakan juga buku rujukan etika Kristen untuk mengevaluasi kasus korupsi. Selain 
itu, buku Etika Kristen oleh Geisler (2013) digunakan sebagai sumber utama dalam penilaian. Berikutnya adalah Pengambilan Keputusan Etis E Faktor-Faktor di Dalamnya oleh Brownlee (2019). Buku ini memakai kajian menilai bahwa keputusan etis dipengaruhi oleh iman, tabiat pribadi dan faktor eksternal. Buku lainnya adalah oleh Magnis-Suseno (2006), Etika. Beliau menyoroti etika dari sudut filsafat moralitas. Di samping itu penulis juga memakai buku teks teologia atau dogmatika yang membahas poin tentang moralitas atau etika. Dengan demikian maka melalui studi ini penulis mendalami isu korupsi yang marak terjadi di Tanah Air yang ditinjau dari segi etika Kristen. Kemudian penulis merumuskan kesimpulan sebagai rangkuman akhir dari penelitian ini dan juga mengajukan implikasi bagi pendidikan anti-korupsi di dalam keluarga Kristen.

\section{Hasil dan Pembahasan}

\section{Pemahaman tentang Korupsi}

Dalam UU No 20 Tahun 2001, korupsi didefinisikan sebagai tindakan melawan hukum dengan maksud memperkaya diri sendiri, orang lain atau korupsi yang berakibat merugikan negara atau perekonomian rakyat. Penekanan korupsi sesuai undang-undang di atas bahwa korupsi berkaitan dengan perbuatan yang bertentangan dengan perundang-undangan yang berlaku di Indonesia. Sehingga, perbuatan yang buruk itu telah mendatangkan kepincangan dalam rencana pembangunan nasional. Tidak ketinggalan masyarakat Transparancy International Indonesia (TII) (2006, p. 3) mendefinisikan korupsi sebagai tindakan memperkaya diri sendiri melalui penyalahgunaan kekuasaan oleh pejabat publik. Motivasi pelaku korupsi menimbun harta dan memperkaya dirinya. Waluyo (2014, p. 180) mengatakan kasus korupsi menuntut upaya tegas aparat dalam pemberantasannya. Beliau menyikapi makin maraknya korupsi yang menggerogoti keuangan negara. Dari paparan di atas dapat dipahami bahwa korupsi sebagai tindakan melawan hukum yang merugikan keuangan negara menjadi keuntungan sendiri. Kekuasaan digunakan sebagai arena menggelapkan anggaran pembangunan. Tindakan ini sebagai pengkhianatan atas sumpah atau janji yang diikrarkan sebelum memangku jabatan tersebut.

Dalam literatur Kristen juga menyoroti kasus korupsi, Boyd (1999, p. 102) menjelaskan nabi Mikha mengecam Israel dan Yehuda karena maraknya korupsi di tengah masyarakat (Mi 2:2; 3:2,9-11). Kramer (2004) juga membenarkan ulasan yang dikemukakan oleh Boyd. Dikatakannya bahwa para pemimpin Yahudi 
dipersalahkan karena menyeleweng dari kekuasaan mereka seperti para hakim telah menerima sogok, nabi-nabi sebagai orang upahan, dan kaum bangsawan suka merampas hak orang miskin (Kramer, 2004, pp. 20-34). Sifat koruptif itu menunjukkan masalah moralitas yang buruk dari para pemimpin di antara orang Israel. Hetharia (2012, p. 7) menilai buruknya moralitas para koruptor. Perilaku mereka telah menyeleweng dari kebenaran firman Allah dan memperlihatkan sifat pemberontakan kepada Tuhan semesta alam. Dampak korupsi menimbulkan ketidakadilan, mengutamakan egoisme dan menyengsarakan orang kecil.

Rupanya kasus korupsi masih merajalela hingga detik ini. Dalam realitas masa kini, korupsi nyata-nyata menggelisahkan banyak orang, terutama orang Kristen. Sulistyo (2020, p. 3) mengetengahkan kasus korupsi yang melibatkan Juliari Batubara, mantan Menteri Sosial RI yang menarik perhatian masyarakat Indonesia karena menerima suap yang berasal dari dana bantuan sosial yang bernilai puluhan miliar rupiah. Sebagai seorang Kristen, Batubara bukannya menghadirkan diri sebagai seorang yang membawa kebaikan bagi bangsa dan negara, malah sebagai pecundang yang memalukan. Kasus ini patut dikritisi secara etika Kristen. Dalam ulasan Geisler (2017, pp. 80-82) bahwa secara etika kebohongan justru sangat melemahkan kesaksian Kristen. Hal ini menimbulkan problem yang dihadapi oleh umat Kristen berkaitan dengan kekuasaan, materialisme, popularitas, keserakahan, hedonisme, serta kenikmatan keduniawian yang berbuah pada sikap mencuri dana pembangunan bagi diri sendiri.

\section{Praktik Korupsi Yang Terjadi}

Praktik korupsi di Indonesia terjadi dalam berbagai bentuk. Salah satunya ialah suap-menyuap. Tamawiwy-Karundeng (2015, pp. 79-80) membenarkan bahwa korupsi di Indonesia berkaitan dengan faktor suap-menyuap. Kutipan ini menandakan bahwa korupsi sebagai arena transaksional antara penyuap (pebisnis) dan penerima (penguasa). Perbuatan kotor itu dilakukan secara bersamasama sebagai hal yang lumrah. Miller (2016, pp. 23-26) mengatakan bahwa korupsi adalah penyalahgunaan wewenang untuk kepentingan umum menjadi kepentingan pribadi. Suatu upaya melampaui wewenang untuk memenuhi kebutuhan pribadi. Semma (2008, pp. 33-34) menguraikan korupsi sebagai tindakan gelap dan tidak sah untuk memperoleh keuntungan secara individu. Di sini juga tampak bahwa korupsi terjadi karena adanya motif dan tujuan tertentu yang hendak dicapai oleh para koruptor dalam melakukan aksi mereka. 
Dari pandangan tersebut dipahami bahwa korupsi menyangkut perbuatan rahasia yang melanggar undang-undang untuk merauk manfaat yang digunakan sendiri. Proyek pembangunan yang bernilai tinggi diselewengkan untuk memperoleh fee bagi pejabat publik tersebut. Motif mereka untuk meraih pemasukan tambahan dari uang negara untuk dikantongi sendiri.

Para ahli mengatakan korupsi bukan hanya terjadi di negeri ini tetapi menjadi problem semua bangsa. Turksen (2018, pp. 43-91) mengatakan bahwa korupsi sebagai kejahatan yang bersifat global. Masalah korupsi menjadi tantangan setiap pemerintahan di seluruh dunia. Negara maju atau berkembang menghadapi persoalan yang sama. Sifat korup telah mengganggu kestabilan keuangan semua negara. Negara Vatikan juga menghadapi masalah korupsi yang serius. Secara global korupsi begitu momok dan mengkhawatirkan semua pihak seperti ditampilkan dalam film pendek The Secret of Trackling Corruption. Ini bukan sekadar musuh kejahatan biasa yang bersifat domestik atau berkaitan dengan suatu kawasan tetapi merupakan kejahatan yang mendunia.

\section{Korupsi sebagai Pelanggaran Moral}

Masalah korupsi merupakan perbuatan buruk yang dilakukan oleh pejabat publik dengan cara menyalahi jabatannya atau kekuasaan yang diembannya untuk memuluskan jalan memperoleh keuntungan finansial bagi dirinya sendiri baik dilakukan sendiri maupun berkolaborasi dengan pihak lain. Miller (2016, pp. 23-26) berpendapat korupsi itu bukan hanya berkaitan dengan masalah pelanggaran hukum oleh pejabat publik melainkan kasus korupsi itu juga berkaitan dengan pelanggaran moral. Definisi ini tepat dan masuk akal bahwa korupsi itu berkaitan dengan moral. Moralitas berperan besar dalam sebuah tindak korupsi. Miller (2016, p. xxviii) malah menyebutkan bahwa tindakan para koruptor bertentangan dengan moralitas yang baik. Anggaran negara untuk pembangunan disunat untuk diambil sendiri. Dalam Kisah Korupsi Kita yang diterbitkan oleh $\mathrm{KPK}$, telah dipaparkan secara terang permainan para koruptor kelas kakap negeri ini (KPK, 2017, p. 22-27). Mereka berbuat curang atau menyimpang dalam menjalankan jabatannya seperti melanggar norma hukum, material, mental dan agama. Secara hukum mereka melanggar undang-undang negara; secara material, mereka mengambil keuntungan dari anggaran pembangunan; secara mental, mereka menyerah terhadap godaan duniawi, bersifat tamak dan rakus; dan secara agama, mereka melanggar nilai-nilai rohani dari agama yang dianutnya. Baik di mata manusia dan Tuhan, tindakan seorang ko- 
ruptor tak dapat ditolerir sebab bersifat jahat, kotor dan laknat. Para koruptor telah mengkhianati bangsanya sendiri. Mereka tidak menjungjung tinggi ajaran imannya; juga merugikan sesama karena mencuri anggaran pembangunan. Hak orang banyak untuk menikmati pembangunan tak tercapai. Masyarakat telah dirugikannya akibat ulah para pencuri tersebut.

Korupsi juga dapat dilihat dari menerima suap atau uang pelicin untuk memperlancar sebuah urusan dengan pihak pemerintah. Zainul dan Arifin (2019, pp. 889-896) mengatakan bahwa korupsi perizinan marak terjadi di kalangan birokrat dan menjadi persoalan serius yang patut ditangani oleh negara. Hal ini terjadi sangat masif di pemerintahan tingkat daerah. Ditengarai para kepala daerah dan jajarannya bertindak secara otoriter seperti seorang raja lalim. Mereka berbuat sesukanya menggunakan uang negara bagi kepentingan kronikroninya.

\section{Koruptif sebagai Realitas Sosial yang Dianggap Lumrah}

Ketua Badan Pemeriksa Keuangan (BPK), Agung Firman Sampurna mengatakan bahwa ada resiko salah urus, pemborosan, korupsi hingga penipuan pada tata kelola anggaran negara di tengah krisis akibat pandemi Covid-19 (CNN Indonesia, 2021). Dalam kondisi yang cukup gawat akibat pandemi, malah masih banyak oknum pejabat yang tidak memperlihatkan kepekaan hati nuraninya dengan melakukan tindak korupsi keuangan pembangunan. Itu berarti anggarannya disunat untuk kepentingan sendiri. Salah satu realita konkrit kasus korupsi yang marak terjadi di daerah. Maulana (2017) dari DetikNews.com mengutip sumber dari KPK bahwa tiga pejabat walikota Cimahi secara berturut-turut terlibat kasus korupsi. Di sini tampak bahwa korupsi itu sebagai realitas sosial dalam laporan media televisi maupun media cetak online. Para koruptor itu memperlihatkan perilaku buruk meminjam julukan yang diberikan Tour (2002, pp. 2-3) dalam novelnya Korupsi. Maka jelas bahwa para pejabat negara ini tidak menunjukkan keteguhan moralitas mereka dalam mengabdi bagi rakyat. Dalam menjalankan tugas mereka terselubungi dengan motif dan karakter yang buruk di kalangan para aparatur negara, yakni bahwa korupsi itu telah menjadi pola yang lumrah biasa saja tak apa-apa dalam berbangsa dan bernegara.

\section{Mentalitas Korup Erat dengan Perlilaku Aparat yang Bobrok dan Buruk}

Dilihat dari kasus-kasus yang terjadi, tampak korupsi lebih dekat pada praktik dalam menjalankan tugas sehingga sering dianggap sebagai perbuatan 
yang lumrah. Semma (2008, pp. 38-39) mengatakan bahwa persaingan di antara partai politik telah meningkatkan kasus korupsi yang menggurita di negeri ini dibandingkan dengan pengaruh budaya yang lazim dikemukakan oleh para ahli atau budayawan. Dilihat dari kasus korupsi yang meningkat membuktikkan bahwa banyak di antara para kepala daerah yang berafiliasi dengan partai politik terlibat kasus korupsi yang diistilahkan sebagai kewajiban mahar (Afriliani, 2020, pp. 64-92). Mengingat bahwa semua kasus korupsi memiliki kesamaan yang sama di semua negara, maka kasus korupsi tidak memiliki kaitan langsung dengan pengaruh budaya. Penyogok bermaksud diperlancar urusannya dengan aparat. Sebaliknya penerima menganggap bahwa pemberian itu sebagai tanda ucapan terima kasih karena sudah membantu masyarakat. Semma (2008, pp. 3839) menduga "korupsi" dianggap sebagai budaya karena pada dasarnya manusia suka memberi dan menerima. Kasus korupsi begitu masif merupakan kontribusi besar dari citra koruptor yang bermoralitas lembek dan rapuh serta dikuasai sifat rakus.

\section{Mengkritisi Korupsi Dari Sudut Pandang Etika Kristen}

Dalam bagian ini penulis merumuskan pokok pikiran tentang alasan kejahatan korupsi dalam pandangan secara etika Kristen. Alasannya bahwa banyak kasus korupsi dalam pemerintahan ternyata melibatkan juga banyak aparat yang berlatarbelakang Kristen, sehingga mengkritisi isu korupsi dari sudut pandang etika Kristen memiliki relevansi bagi kepentingan warga gereja yang mengambil bagian dalam pemerintahan:

\section{Pelanggaran terhadap Kebenaran Absolut}

Manusia hidup dalam alam yang bersifat absolut. Manusia tidak hidup secara liar tanpa hukum tetapi berada dalam koridor yang diatur oleh hukum yang absolut sehingga dapat tercipta rasa adil dan benar. Dalam kaitan itu, Geisler (2017, pp. 79-85) menggambarkan bahwa manusia diciptakan bukan untuk hidup sebebas-bebasnya tetapi terkontrol dalam prinsip norma yang absolut. Norma absolut dalam pandangan Kristen adalah firman Allah. Apabila manusia hidup di luar kebenaran yang absolut tersebut maka tindakannya bersifat fasik dan jahat. Maka ketika para birokrat Kristen terlibat korupsi mereka menempatkan diri mereka di luar hukum absolut. Tindakan itu merugikan Kekristenan dan kepentingan umum. Karena mereka tidak mengutamakan kebenaran absolut dalam hidupnya. Sebaliknya tunduk pada hawa nafsu dan 
mencuri dana pembangunan dan merugikan kepentingan umum. Geisler (2017, pp. 75-85) menegaskan kebenaran absolut adalah prinsip dasar yang bersumber dari ajaran Alkitab. Norma ini patut dijunjung tinggi oleh setiap orang Kristen. Tuntutan norma bagi orang Kristen dalam pandangan Brownlee (2019, p. 191) adalah bahwa setiap orang Kristen dituntut mematuhi Allah. Firman Allah dipakai sebagai standar hidup orang percaya. Beliau menegaskan bahwa dalam keputusan etis orang Kristen memerlukan bimbingan Roh Kudus sehingga keputusannya mengedepankan firman Allah sekaligus taat kepada Allah (Brownlee, 2019, p. 191). Dengan berpegang pada norma Alkitab akan menuntun setiap orang Kristen berperilaku yang benar, termasuk dalam menjalankan tugas dalam pemerintahan. Akan tetapi jika ternyata terlibat korupsi, ia dipandang sebagai pemberontak terhadap kebenaran absolut.

Pada prinsipnya jika orang Kristen yang duduk dalam pemerintahan hidup di luar kontrol norma absolut maka ia cenderung berbuat sesuka hatinya dalam menjalankan tugas dan tanggung jawabnya. Alkitab mengatakan bahwa dosa berada di atas semua pelanggaran terhadap hukum Allah, dan karena itu manusia dipandang bersalah di hadapan Allah dan layak memperoleh hukuman (Rm 3:23; 6:23; Yes 59:2). Tindakan korupsi adalah perbuatan jahat di mata Tuhan. Artinya mereka tidak memenuhi standar Tuhan bagi mereka di dalam memerintah (bdk. Rm 13:1-4) bahwa mereka adalah hamba Allah untuk melayani kepentingan rakyat.

Penyebab Kegagalan dalam Menjaga Keutuhan Integritas Pribadi

Tentang norma standar Geisler (2017, pp. 150-151) mengatakan bahwa dalam etika Kristen, firman Allah dipakai sebagai standar moral utama bagi kehidupan manusia. Karena di dalamnya tergambar karakter Allah yang berdaulat atas kehidupan manusia. Dari pandangan Geisler menegaskan bahwa sebagai ciptaan-Nya, manusia patut tunduk secara total pada norma Alkitab yang berdaulat atas hidup mereka.

Namun jika manusia menyangkali norma itu dalam hidupnya maka ia melanggar ketetapan Allah tersebut. Di situlah ia dipandang sebagai orang fasik atau berdosa. Berkhof (1994, p. 108) mengatakan bahwa kejahatan atau perbuatan dosa termasuk wilayah moral. Seseorang berbuat dosa berarti melanggar norma standar Allah tersebut. Artinya ia tidak bertanggung jawab di hadapan Tuhan dan hidup secara liar atau fasik. Lebih jauh Berkhof menjelaskan kata Ibrani avel dan 'avon menunjukkan bahwa dosa itu berkaitan dengan kekurangan 
integritas atau kejujuran; meleset dari arah yang ditujui. Pelanggaran yang realistis terhadap hukum atau melanggar perjanjian yang telah disetujuinya (Berkhof, 1994, p. 108). Itu berarti para koruptor dipandang sebagai orang tidak memiliki integritas pribadi, semaunya sendiri dalam menjalankan tugas dan tanggung jawabnya.

Tentang masalah integritas dilihat oleh Brownlee (2019, pp. 131-133) bahwa integritas itu perlu berakar dalam diri seseorang supaya ia mampu berdiri teguh dan tidak diombang-ambingkan oleh keduniawian. Berpendirian teguh itu dimaksud agar ia memiliki kehendak yang utuh atau bulat dalam menjalankan tugas dan pengabdiannya. Lanjut beliau mengatakan bahwa penerapan integritas bermuara pada sikap menolak jalan yang tergampang seperti godaan terhadap hawa nafsu materialisme atau keserakahan yang cenderung mendapatkan harta secara sewenang-wenangnya sendiri (Berkhof, 1994, p. 132). Berdasarkan kutipan di atas, Brownlee (2019) memandang bahwa tindakan sewenang-wenang terhadap tugas dan tanggung jawab seseorang memiliki unsur berbuat jahat dan curang untuk memperoleh kekayaan secara ilegal dengan melawan suara hati nuraninya sendiri, termasuk melawan hukum dan norma perundang-undangan yang sudah diketahuinya untuk melakukan korupsi.

Para koruptor melayani keinginan daging dan hawa nafsu untuk memperkaya diri sendiri dengan cara yang bertentangan dengan sepuluh hukum Tuhan: mencuri (Kel 20:15, 16). Dua anak dari Imam Eli yakni Hofni dan Pinehas juga terlibat kasus korupsi. Keduanya menerima suap dan melakukan kekerasan (1 Sam 2:12-17). Merrill (1985) mengatakan Kitab Hakim-Hakim menegaskan bahwa pada masa itu orang Israel tidak memiliki raja. Semua orang merasa dapat melakukan apa yang diinginkannya (Hak 21:25). Hal ini juga memengaruhi sikap dan perilaku para imam yang bertugas pada masa itu. Imam Eli, tampak sebagai seorang yang bermoral. Tetapi ia kehilangan kendali atas Hofni dan Pinehas kedua anak laki-lakinya. Mereka berbuat sesukanya ter-hadap kurban bakaran yang dipersembahkan kepada Tuhan. Mereka mengam-bilnya untuk kepentingan diri sendiri (Merrill, 1985, pp. 434-435). Dengan kata lain perbuatan mereka memenuhi unsur korupsi karena mengambil hak Tuhan untuk kepentingan sendiri. Secara etika Taurat, kedua anak imam Eli pun memperlihatkan moralitas yang buruk, bobrok dan bejat (Nggebu, 2007, pp. 180-182). Keduanya melakukan perbuatan ilegal dan bertentangan dengan ketetapan Tuhan.

Malah pada zaman Yesus Kristus, para imam juga menyeleweng dari jabatan mereka dengan mengutip biaya sewa dari para pedagang di halaman Bait 
Allah untuk dikantongi sendiri (bdk. Mat 21:12; Mrk 11:15, 16). Perbuatan koruptif mereka yang sok suci itu dibenci Tuhan. Yesus secara tegas mengecam perbuatan kotor, busuk dan fasik dari para ulama ulung Yahudi tersebut. Buzzell (1995, p. 928) menafsirkan Amsal 10:31-32 berkaitan dengan karakter dari orang fasik. Kedua ayat ini menegaskan tentang perilaku orang yang ber-paling dari apa yang normal. Mereka melanggar norma yang berlaku di tengah umat manusia. Firman Allah sebagai standar hidup dilanggar. Kitab Amsal 12:5-9 membedakan antara karakter orang benar dengan orang jahat. Untuk teks ini Buzzell (1995) mengutarakan pandangannya yang membedakan antara orang benar dan orang jahat. Orang benar memiliki rencana yang mulia, berbuat adil, jujur dan mengutamakan kepentingan orang lain atau menolak perbuatan hanya untuk diri mereka sendiri. Sedangkan orang jahat menasihati orang lain dengan cara yang menipu, bersifat tidak jujur dan mementingkan diri sendiri. Dengan demikian sebuah pikiran, tindakan dan kata-kata sama konsistennya dengan karakternya (Buzzell, 1995, pp. 930-931). Itu berarti tujuan hidup orang fasik ialah memperdaya orang lain. Maka dalam kaitan dengan perilaku korup yang terjadi di Indonesia pada masa kini ialah mengge-rogoti keuangan negara sebagai perilaku fasik. Boleh dikatakan mulut orang fasik (para koruptor) hanya tahu tipu muslihat (bdk. Ams 10:32).

Rasul Petrus menelisik juga sifat para koruptor yang dikuasai hawa nafsu, keinginan daging seperti orang yang tidak mengenal Allah (1 Ptr 4:3). Maka tepat sekali Wheaton (2000, p. 864) manafsirkan 1 Petrus 4:3 bahwa semestinya orang Kristen yang diberi tugas termasuk dalam pemerintahan wajib menunjukkan teladan, bukannya menjalankan wewenang tanpa batas dan memeras orang. Akan tetapi mereka telah berbuat sesukanya dan menjadi orang yang berbuat jahat. Mereka tidak memperlihatkan teladan bagi masyarakat.

Para pemimpin sesungguhnya ditetapkan Allah untuk melayani warga masyarakat (bdk. Rm 13:1-11) dengan adil, benar dan takut akan Tuhan. Namun pada kenyataannya para birokrat itu berperan aktif dalam mensponsori tindak korupsi. Mereka bersifat oportunistis dengan mengubah kepentingan umum menjadi kepentingan pribadi. Tipu muslihat menguasai hidup mereka sehingga kelakuan mereka bertentangan dengan kebenaran firman Allah.

Mencintai Materi Lebih daripada Tuhan

Para koruptor baik yang beragama Kristen maupun berkepercayaan lain telah menyeleweng dari jabatannya untuk melayani rakyat menjadi sarana em- 
puk untuk memperkaya diri sendiri dengan mencuri dana pembangunan dari APBN. Tampaknya uang begitu menggoda dan memikat hati mereka sehingga mereka kehilangan akal sehat dan berbuat curang. Firman Allah berkata "Akar segala kejahatan adalah cinta uang" (1 Tim 6:10). Guthrie (2000, p. 726) mengatakan orang yang menyibukkan diri menjadi kaya akhirnya mendatangkan kerugian bagi dirinya yakni disesatkan dari iman (secara negatif) dan mengalami kehancuran hidup atau tidak beruntung (secara positif). Hal itu berlawanan dengan upaya yang benar dari kesalehan (Guthrie, 2000). Itu berarti para koruptor dikuasi oleh kejahatan karena tergoda dengan harta duniawi. Materi dianggap lebih berharga dari pada citra dirinya. Mengurbankan mora-litas pribadinya demi meraup materi yang bukan haknya. Hidup mereka seper-ti orang lalim yang menindas kebenaran (bdk. Rm 1:18; 6:13; 1 Kor 3).

Ditengarai ada motif tertentu dalam para koruptor ketika melakukan korupsi. Secara tidak sadar mereka terjebak dalam konsep oportunistis untuk tujuan hedonistik. Bersifat oportunistis karena menggunakan jabatannya sebagai kesempatan untuk memperkaya dirinya. Bone (2020, p. 138) mengatakan bahwa orang terlibat korupsi karena tercipta kesempatan seperti regulasi yang buruk, birokrasi dan sistem hukum yang tidak efesien. Di sini para koruptor mensiasati cara untuk tindak koruptif. Di samping itu, sebagai pejabat mereka juga tergoda dengan gaya hidup mewah sehingga terdorong melakukan kecurangan. Brownlee (2019, p. 144) mengusulkan agar orang Kristen patut memikul salib dengan menolak berbuat yang bertentangan dengan ajaran Kristus termasuk menolak godaan ketamakan. Namun yang sebaliknya yang terjadi berarti ia mengkhianati imannya dan berbuat yang jahat maka secara etika ia bukan orang yang meneladani Yesus Kristus.

Koruptor tersebut lebih mengutamakan materi ketimbang iman, mereka mencari keuntungan sendiri. Memuaskan diri mereka dengan kemewahan yang sementara dan mengabaikan kebenaran dan keadilan. Ia tergolong orang fasik karena hanya memuaskan hawa nafsu daging mereka. Mereka tidak hidup sesuai ajaran kebenaran Allah. Handayani $(2019$, p. 7) mengatakan bahwa korupsi dalam Perjanjian Lama erat kaitannya dengan praktik politeisme. Tampak bahwa ada relasi antara praktik korupsi dengan pola hidup para penyembahan berhala yang cenderung berpesta pora dan pelanggaran moralitas. Bahwa terjadi penyelewengan terhadap kekuasaan untuk memperkaya diri demi menjalankan praktik keagamaan kekafiran (Handayani, 2019, pp. 6-7). Para koruptor yang dikuasai oleh keserakahan tidak memiliki bagian dalam Kerajaan Kristus (bdk. 
Ef 5:5) karena mempraktikkan cara hidup kefasikan. Mereka telah dibutakan oleh ilah zaman ini (2 Kor 4:4) sehingga gemar berbuat yang jahat dan menjadi budak materialisme serta mendewakannya.

Kehadiran orang Kristen dalam pemerintahan itu penting untuk menawarkan prinsip hidup dalam iman Kristen yang mencukupkan diri dengan apa yang ada padamu sebagaimana yang diajarkan Tuhan. Dawa (2015, pp. 54-78) mengusulkan agar gereja seyogianya tidak mengambil sikap apolitik melainkan membuka diri untuk berperan aktif secara nyata dalam kehidupan berbangsa dan bernegara, termasuk gereja-gereja yang berlatar belakang etnis Thionghoa. Gereja juga dapat berperan untuk mendidik dan membina umat memiliki pandangan yang benar tentang konsep anti-korupsi yang sejalan dengan kebenaran firman Allah. Firman Allah mengatakan: "Cukupkanlah dirimu dengan apa yang ada padamu" sebagai kebenaran yang memagari hidup seseorang dari godaan korupsi. Gagasan pola hidup sederhana bukanlah ide yang ketinggalan zaman. Tetapi falsafah hidup ini adalah bagian dari firman Allah hidup dan berkuasa dalam batin dan pikiran orang percaya di sepanjang sejarah dunia (bdk. Luk 3:14; Ibr 13:5). Menurut penegasan Stibbs (2000, pp. 800-801) pola hidup cukupkan diri dengan apa yang ada padamu sudah menjadi kebiasaan pada zaman Perjanjian Lama bahwa orang beriman diajar untuk beriman atau bergantung pada pemeliharaan Allah (bdk U1 31:6; Yos 1:5). Janji Allah itu akan dipenuhi bagi mereka yang beriman kepada-Nya.

\section{Manusia telah Tercemar}

Di lain pihak Tuhan sesungguhnya bersukacita jika umat-Nya melakukan kebenaran dan keadilan dalam dunia ini. Mereka yang dipercayakanNya menjadi pejabat dalam pemerintahan sebagai sarana yang dipakai-Nya untuk mengalirkan kebenaran dan keadilan di tengah masyarakat. Akan tetapi tujuan itu menjadi terhambat karena perilaku mereka yang buruk dan bobrok. Enns (2003, p. 384) mengatakan bahwa pada dasarnya manusia telah tercemar secara intelek (2 Kor 4:4) dan kehendak (Rm 1:28). Cemar secara intelek karena gagal memahami kebenaran Injil dan pikirannya dikuasai oleh keduniawian. Dan secara kehendak mereka menolak keberadaan Allah karena pikiran mere-ka dikuasai oleh hawa nafsu dan perbuatan-perbuatan kotor. Hal ini dapat dikaitkan dengan tindakan para koruptor yang dikuasai oleh hawa nafsu dan materialisme untuk memperkaya diri sendiri dengan mengambil dana pembangu- 
nan untuk dirinya. Mereka telah mencemarkan diri mereka sendiri karena hidup demi kepentingan keduniawian saja.

Maka tatkala seorang aparat negara berhadapan dengan lalu lintas anggaran miliaran rupiah di depan matanya, naluri nafsu-rakus yang dibawa sejak lahir sangat menggodanya. Maka ia tak segan-segan menempuh berbagai cara kerja dari akal bulusnya untuk memuaskan hawa nafsunya tanpa mempertimbangkan kebenaran absolut-dia pun terseret ke dalam arus duniawi: korupsi. Tabiatnya jahat. Dikuasai oleh keserakan dan pementingan diri sendiri. Tuhan Yesus mengatakan “...orang jahat mengeluarkan barang yang jahat dari perbendaharaannya yang jahat" (Luk 6:45). Orang bertindak begitu karena melepaskan moralitas Kristen dalam batinnya. Brownlee mengatakan tabiat orang Kristen semestinya tidak dibiarkan lepas dari Kristus (Brownlee, 2019, p. 119). Pada saat ia melepaskan diri dari relasi yang harmonis dengan Kristus maka ia jatuh ke dalam pencobaan. Dikaitkan dengan tindak korupsi, maka orang yang menjauhkan diri dari Tuhan akan bertindak menyimpang dari tugas dan tanggung jawab.

\section{Dikuasai Motif Pragmatisme}

Darmaputra (2006, pp. 156-157) mengatakan pada zaman sekarang orang cenderung bersifat pragmatis dan materialisme. Maksudnya bahwa segala sesuatu dilihat atau dikerjakan oleh manusia sering dipahami dari segi kegunaan dan keuntungan. Jika seseorang duduk dalam jabatan penting di pemerintahan maka bisa saja ia melihat kedudukan itu dari segi pragmatis dan materialismenya. Jabatan itu dilihat dari segi untungnya. Kedudukan seorang pejabat begitu penting dalam pemerintahan karena berurusan dengan kekua-saan dalam pengambilan keputusan atau menentukan kebijakan. Akhir-akhir ini laporan di media masa dan televisi tentang kasus kepala desa yang menyelewengkan anggaran desa untuk kepentingan pribadi dengan cara merekayasa proyek dan laporan keuangannya-akhirnya terendus aparat penegak hukum. Pejabat yang pragmatisme akan berpikir secara pragmatis pula. Saat menangani proyek pembangunan, dia melihat apa untung bagi dirinya. Ada godaan agar dapat bagian dalam sebuah proyek yang ditangani seperti yang terjadi dengan para penyelenggara paling terdepan, mencuri dana desa. Korupsi senantiasa menggeliat dalam benak para kepala desa tersebut. Mengatur strategi untuk meraih keuntungan bagi diri sendiri. Kegunaan dan keuntungan selalu dikaitkan dengan material. Jabatannya juga dilihat dari segi manfaatnya. Karena duduk di 
kursi empuk maka ia bisa menangani proyek yang beri keuntungan. Inilah segi pragmatis dari sebuah jabatan untuk meraih materi bagi dirinya. Sikap pragmatisme dari para pejabat modern dengan mencari keuntungan. Ada kekuasaan dan ada keuntungan materi. Sikap mental dan moralitas seperti ini sangat merugikan kesaksian kekristenan di tengah masyarakat karena orang Kristen yang melakukan korupsi tidak menjadi teladan bagi masyarakatnya.

\section{Dikuasai Hawa Nafsu Daging}

Enns (2003, p. 387) mengatakan manusia sering menghadapi berbagai ujian dalam hidupnya termasuk hawa nafsu dari daging (1 Yoh 2:16; bdk. Mat 4:1-11). Godaan ini sering membawa manusia jatuh dalam dosa (baca: korupsi). Artinya, ia tunduk pada godaan daging ( $\operatorname{sar} x$ ) yang berkaitan dengan materi (Enns, 2003, p. 387), yakni menyalahgunakan jabatannya untuk mendapatkan keuntungan finansial. Di situ sebenarnya hawa nafsu terhadap uang telah menawannya. Magnis-Suseno (2006, p. 23) mengatakan tindakan yang dilakukan oleh seseorang senantiasa berkaitan dengan motif dan tujuan tertentu. Dalam kajian ini tampak ada kaitan antara motif dan tujuan dalam setiap kasus korupsi. Di sini muncul masalah secara etika Kristen berkaitan dengan manusia (koruptor) dan uang yang ada dalam kekuasaannya guna mendapatkan keuntungan pribadi.

\section{Melemahkan Hati Nurani Rakyat}

Melalui tindak korupsi, para koruptor telah menciderai hati nurani warga masyarakat. Hak setiap warga negara untuk menikmati hasil pembangunan yang adil dan merata sesuai anggaran negara menjadi berantakan karena kejahatan mereka. Semma (2008, p. 56) mengatakan akibat korupsi kualitas barang dan jasa semakin merosot. Dana bantuan sosial yang diselewengkan tentu saja berdampak pada menurunnya kualitas natura yang diterima rakyat. Sementara itu Setiadi (2018, p. 252) melihat dampak korupsi terhadap mentalitas generasi muda yang menyaksikan perilaku buruk di dalam tubuh pemerintahan. Mereka mempertontonkan kelakuan yang buruk dan busuk. Kelakuan aparat pemerintah yang kotor dapat mematahkan semangat mereka dalam meraih masa depan yang lebih baik. Mereka tidak mampu menjalankan tugas dan tanggung jawabnya sebagaimana mestinya sehingga mempertontokan kelakuan yang bertentangan dengan kaidah dan norma dalam masyakarat. Setiadi $(2018$, p. 252) melihat bahwa maraknya korupsi menyebabkan keresahan sosial di tengah 
masyarakat. Dalam kaitan tanggung jawab, Brownlee (2019, pp. 30-31) mengatakan bahwa orang Kristen dituntut untuk melakukan kehendak Allah di da-lam hidupnya; mengutamakan nilai-nilai Kristen dan mematuhi norma-norma etis yang berlaku.

Dalam pandangan Geisler (2017) orang Kristen semestinya mereka dituntut lebih taat kepada norma Alkitab. Beliau menegaskan bahwa pada prinsipnya norma yang dinyatakan secara umum maupun secara khusus yakni firman Allah diberikan kepada manusia atau semua orang supaya menaatinya secara rasional maupun moral. Secara khusus norma firman Allah diberikan kepada orang percaya. Karena itu semestinya mereka memiliki kesadaran lebih besar dalam menunaikan tanggung jawabnya (Geisler, 2017, pp. 151-154). Lembang (2020, pp. 16-26) menilai bahwa orang yang memiliki kesadaran etis dan hidup sesuai firman Allah dimampukan untuk menampik tawaran korupsi. Hal serupa dipandang penting juga oleh Dharmawan (2019, pp. 17-32) bahwa seseorang perlu memiliki kesadaran dan pengetahuan etika sebagai benteng pelindung dari godaan korupsi. Dari kutipan di atas menunjukkan bahwa setiap orang Kristen dalam menjalankan roda pemerintahan diharapkan memiliki sikap sadar diri bahwa korupsi pada dasarnya bertentangan dengan prinsip etika Kristen.

Dengan demikian dilihat dari perbuatan, akibat dan kewajiban, maka para koruptor itu telah gagal dalam memenuhi tuntutan etika Kristen. Perbuatan mereka begitu jahat karena melakukan korupsi yang mengakibatkan kerugian bagi negara dan rakyat dan gagal dalam menunaikan kewajiban mereka dalam menjalankan pemerintahan yang jujur dan bersih sehingga tidak menunjukkan teladan bagi generasi penerus. Sikap dan perbuatan mereka sebagai kejahatan dan kefasikan yang dipandang sebagai pemberontakan kepada Tuhan.

Tentu saja dampak korupsi merusak citra aparatur negara itu sendiri; menurunkan kualitas pembangunan; juga menciderai moralitas anak bangsa yang mengakibatkan rendahnya respek generasi muda terhadap lembaga penegak hukum atau institusi negara tempat para koruptor beraksi mengge-lapkan anggaran pembangunan untuk kepentingan umum. Waluyo (2014, pp. 169-182) melihat pentingnya penegakan hukum yang konsekuen sebagai langkah antisipasi dan pencegahan korupsi. Tentu saja anjuran bijak ini perlu disikapi oleh para penegak hukum yang menganut iman Kristen agar memegang teguh nilai-nilai Alkitab dalam menjalankan tugas mereka. 
Merusak Moralitas dan Spiritualitas

Sebagai makhluk ciptaan Tuhan, setiap individu unik dan khas di mataNya. Kepribadian yang khas itu sebagai model dalam pengabdian di tengah warga masyarakat. Maka citra diri itu sepatutnya dijaga dan dijunjung tinggi oleh yang bersangkutan. Mampu bertahan dalam memegang prinsip kebenaran yang dianutnya. Begitu juga dengan para penyelenggara negara, seyogianya menjunjung tinggi kebenaran yang diimaninya untuk diaplikasikan dalam dunia kerja. Sapta Sunariyanti (2018, pp. 110-112) memandang bahwa seyogianya mereka memiliki karakter seperti Kristus. Itu berarti Yesuslah menjadi model bagi setiap orang Kristen. Dalam kehidupan-Nya selama di bumi, Yesus Kristus menunjukkan bahwa diri-Nya lebih mementingkan kepentingan umum daripada diri-Nya sendiri. Secara utuh dan total Dia telah menyerahkan diriNya, mati pada salib demi keselamatan manusia (bdk. Flp 2:1-11).

Namun jika terlibat korupsi, para koruptor telah merendahkan harkat dan martabatnya. Lembaran sejarah mencatat para koruptor sebagai peng-khianat bangsa, penjahat dalam pembangunan negara dan pencuri kelas kakap karena menggunakan kekuasaan untuk memperkaya diri (KPK, 2017, p. 43-78). Citra buruk itu akan melekat kuat sampai generasi selanjutnya. Ini warisan yang kelam yang menciderai keharuman dan nama baik keluarga inti dan familinya sendiri, yang oleh Semma (2008, pp. 39, 59-60) dikatakan bahwa dampak kerusakan moral dan spiritualitas dari para koruptor itu bisa terasa bagi generasi berikutnya hingga berabad-abad kemudian. Dalam pandangan Brownlee (2019, p. 238), bahwa tanggung jawab setiap orang Kristen adalah menunjukkan kepekaan terhadap orang lain. Karena Allah memanggil mereka untuk memperhatikan kebutuhan sesamanya (Kel 3:7-8; Mzm 107:41; Mat 25:31-46). Lanjutnya bahwa di sisi lain ada persaingan ketat di antara manusia sehingga lebih mengutamakan kepentingan diri sendiri yang mengakibatkan mereka kurang memperhatikan kebutuhan orang lain (Brownlee, 2019, p. 155). Dengan demikian jelas sekali para koruptor mencederai kepekaannya terhadap kepentingan rakyat dan juga merugikan kepentingan umum. Tuhan muak dan benci terhadap setiap perilaku yang buruk di hadapan-Nya. Di hari penghakiman Yesus mencela orang yang tidak peka terhadap orang lain dan bahwa Ia akan mencampakkan mereka ke dalam api yang kekal (Mat 25:41). Jika demikian maka korupsi itu suatu perbuatan kesia-siaan belaka di muka bumi ini! 


\section{Panggilan Kristen Bagi Pendidikan Anti Korupsi}

Orang Kristen memiliki keyakinan bahwa korupsi sebagai perilaku yang buruk dan busuk di tengah masyarakat itu perlu disikapi dengan membangun pendidikan anti korupsi bagi umat Allah. Pertama, gereja dapat berperan membangun perilaku dan citra Kristen sejak dini, masa anak (usia SD). Rifai (2018, p. 13) memandang bahwa seyogianya anak sejak dini perlu diperkenalkan tentang masalah anti korupsi supaya mereka terbiasa hidup jujur dan bertanggung jawab secara etika Kristen. Mempersiapkan citra mereka agar hidup sesuai Injil (bdk. Rm 1:16-17); mereka adalah ciptaan baru dalam Kristus (2 Kor 5:17); mereka telah diubahkan agar hidup sesuai dengan kehendak Allah ( $\operatorname{Rm} 12: 1-2 ;$ Ef 2:8-10). Citra Kristen ini perlu ditanamkan sejak dini supaya tahu kedudukan mereka di hadapan Tuhan dan mereka terbiasa hidup dalam kebenaran Allah.

Kedua, pentingnya arahan dan bimbingan secara kontinu bagi generasi muda yakni pada usia remaja. Mereka ditanamkan pola hidup jujur, bertanggung jawab dan setia dalam tugasnya (Mat 25:21; Mrk 16:10; Luk 19:17; Gal 4:18; Kol 4:1; Tit 2:7). Tidak mencintai uang atau meteri (1 Tim 6:10) bahwa cinta akan uang sebagai dosa yang dibenci Tuhan (2 Tum 3:2). Kebenaran yang ber-sumber dari firman Allah ini perlu ditanamkan sejak dini bagi anak. Dandirwalu (2018, p. 100) menjelaskan bahwa orang tua dapat menggunakan metode nasihat sebagai bimbingan terhadap anak remaja tentang masalah korupsi yang sedang marak terjadi di tengah masyarakat. Itu berarti wawasan anti korupsi perlu dibentuk dalam pemahaman anak agar memahami bahwa korupsi itu bertentangan dengan iman dan juga etika. Mereka dibina dalam imannya agar mampu hidup benar dan berperilaku yang mulia. Salah satu pola yang dapat ditempuh melalui pembangunan karakter atau moralitas hidup dalam kebenaran firman Allah di dalam keluarga baik melalui pemuridan atau pembinaan iman maupun pendalaman Alkitab (PA). Keluarga inti sendiri sebagai tempat pembinaan iman dan tata nilai bagi anak yang efektif karena anak sebagai generasi muda turut dipersiapkan menjadi pribadi yang dewasa dalam Kristus; menghidupi teladan Kristus yang rela berkurban bagi kepentingan umum bukan diri sendiri. Hal ini sejalan dengan tujuan pembangunan bangsa untuk kepentingan umum.

Ketiga, secara praktika generasi muda dilatih atau diarahkan untuk cerdas dalam menggunakan uang. Salah satu bentuk praktisnya yakni mereka patut mengembalikan sisa uang belanja titipan orang tuanya lengkap dengan nota bonnya. Mereka juga perlu diingatkan untuk tidak menyentuh sisa uang tersebut tanpa izin atau mentang-mentang ini uang ayah atau ibu berarti uang dia juga. 
Secara moral dan etis, mereka tidak patut menggunakan uang yang bukan miliknya. Mereka diajar untuk bertanggung jawab mulai dari hal kecil maka ia akan terbiasa menjalankan tugas yang lebih besar. Ketika kelak generasi muda Kristen mendapat kesempatan menjalankan roda pemerintahan maka mereka dapat menghadirkan diri sebagai utusan Kristus yang bekerja dengan moralitas Kristen yang bebas dari segala bentuk kecemaran dunia ini. Keluarga sebagai tempat strategis menghasilkan generasi muda yang mencintai Tuhan dan firman-Nya sehingga tatkala mereka mengabdi di tengah masyarakat akan memegang teguh keyakinan iman mereka yang tangguh dan kokoh, berintegritas, mengedepankan kepentingan publik, dan menjadi pribadi yang mengutamakan pengaruh firman Allah di dalam hidup mereka.

Keempat, membangun moralitas bagi aparat Kristen yang duduk dalam pemerintahan. Dalam dunia pemerintahan menanti partisipasi Kristen dalam pembangunan bangsa dan negara. Hasibuan (2017, p. 6) memandang pentingnya membangun moral bagi para elite yang berperan sebagai tokoh politik di tengah masyarakat. Maka watak dan moralitas aparat negara yang terbentuk sesuai Injil Kristus akan melindungi citra dirinya dari tindak pidana korupsi yang bertentangan dengan kehendak Allah, bahkan tidak akan pernah berpikir tentang korupsi itu sendiri karena fokus perhatiannya hanya ditujukan pada pengabdian yang tulus dan ikhlas bagi pembangunan warga masyarakat, bangsa dan negara.

Kelima, secara ekstern gereja perlu aktif mengampanyekan pandangan yang anti korupsi di tengah jemaat atau masyarakat luas sebagai suara kenabian. Handayani (2019, p. 7) menegaskan bahwa pentingnya gereja menyuarakan pandangan yang tegas tentang sikap anti korupsi sebagai upaya menyikapi maraknya kasus korupsi di Tanah Air. Dalam kaitan itu, gereja telah berperan mengampanyekan tentang karakter Kristen dalam melakukan firman Allah sebagai kebenaran absolut, menolak ketidakadilan, penyelewengan ja-batan agar setiap aparat negara dapat menjalankan roda pemerintahan dengan takut akan Tuhan dan menjunjung tinggi harkat dan martabat sebagai umat Allah yang diutus Tuhan di tengah masyarakat (bdk Rm 13:1-8).

\section{Implikasi}

Menyikapi realitas korupsi yang makin membara di negeri ini maka tantangan bagi Gereja adalah turut membentuk watak dan tata nilai Kristen bagi warga gereja melalui pendidikan anti korupsi bagi generasi muda sehingga jika 
kelak mereka diberi kesempatan menjadi wakil Allah dalam pemerintahan maka mereka akan mengabdi bagi masyarakat dengan menjunjung tinggi kebenaran, keadilan dan moralitas Kristen yang utuh, kokoh dan teguh. Secara praktis mereka dengan gagah berani akan menolak keinginan daging dan sifat keduniawian yang menggoda mereka serta memiliki moralitas yang berpedoman pada Injil dan senantiasa memancarkan kasih Kristus bagi dunia.

\section{Kesimpulan}

Berdasarkan penelitian ini penulis menjawab permasalahan di atas bahwa secara etika Kristen sifat koruptif sebagai tindakan yang dibenci Allah karena para koruptor dikuasai oleh keserakahan. Para koruptor lebih mengutamakan materialisme dan hedonisme sebagai bentuk mendewakan materi sebagai yang utama dalam hidup mereka. Itu berarti kebenaran Allah telah disingkirkan dari kehidupan mereka. Tindakan korupsi dipahami oleh Paulus sebagai karakter jahat yang tak memiliki tempat dalam Kerajaan Kristus (bdk. 1 Kor 6:9; Ef 5:5). Dalam konteks kekinian dampak dari kejahatan korupsi telah membuat koruptor tersebut kehilangan kesempatan terbaiknya menjadi wakil Kristus dalam pemerintahan. Kehadiran mereka dalam pemerintahan bukannya memberkati dunia, malah sebagai pecundang dan pencuri. Mereka bukannya melayani Allah yang Mahakudus, tetapi memuaskan kedagingan-keduniawiannya.

\section{Daftar Rujukan}

Afriliani, W. A. N. (2020). Disparitas Pengaturan Tentang Mahar Politik dalam Undang-undang Pemilu dan Undang-undang Pilkada. Institut Agma Islam Negeri Purwokerto.

Arifin, M. Z., \& Irsan. (2019). Korupsi Perizinan Dalam Perjalanan Otonomi Daerah di Indonesia. Lex Librum: Jurnal Ilmiah Hukum, 5(2), 887-896.

Berkhof, L. (1994). Teologi Sistematika: Doktrin Allah: Doktrin Manusia Jilid 2 (Y. Thianto, Ed.). Jakarta: Lembaga Reform Injili Indonesia.

Bone, H. (2020). Kesadaran Publik di Indonesia: Survei Respons Publik Terhadap Korupsi dan Peran Akuntan. Jurnal Akutansi, Ekonomi Dan Manajemen Bisnis, $8(2), 134-140$.

Boyd, F. M. (1999). Kitab Nabi-Nabi Kecil. Malang: Gandum Mas.

Brownlee, M. (2019). Pengambilan Keputusan Etis \& Faktor-Faktor Di Dalamnya. Jakarta: Gunung Mulia.

Buzzell, S. S. (1995). Proverbs. In The Bible Knowledge Commentary (pp. 1-1589). 
Wheaton: Victor Books.

CNN Indonesia. (2021, January 11). BPK Ungkap Risiko Korupsi Dana APBN di Masa Pandemi Corona. CNN Indonesia. Retrieved from https:/ / www.cnnindonesia.com/ekonomi/20210111112407-532-

592071/bpk-ungkap-risiko-korupsi-dana-apbn-di-masa-pandemi-corona

Dandirwalu, R. (2018). Pembinaan Anti Korupsi dalam Keluarga Kristen dan Muslim di Kota Ambon. Wawasan: Jurnal Ilmiah Agama Dan Sosial Budaya, 3(1), 90-100. https://doi.org/10.15575/jw.v3i1.1334

Darmaputera, E. (2006). Spiritualitas Siap Juang. Jakarta: Gunung Mulia.

Dawa, M. D. L. (2015). Menyoal Sikap Gereja Terhadap Politik. Jurnal Theologi Aletheia, 17(9), 54-78.

Dewantara, A. W. (2018). Sikap Lepas Bebas Kristiani Sebagai Bahasa Teologi Antikorupsi. In Etika dan Religiusitas Anti-Korupsi (pp. 1-22). Yogyakarta: Global Ethics.

Dharmawan, N. A. S. (2019). Etika, Agama, Dan Cinta Sebagai Modal Dasar Akuntan Dalam Memberantas Korupsi. Jurnal Ilmiah Akuntansi, 3(1), 17-32. https:// doi.org/10.23887/jia.v3i1.16626

Enns, P. (2003). The Moody Handbook of Theology; Buku Pegangan Teologi. Malang: Literatur SAAT.

Geisler, N. L. (2013). Etika Kristen: Pilihan E Isu Kontemporer. Malang: Literatur SAAT.

Geisler, N. L. (2017). Etika Kristen: Pilihan dan Isu Kontemporer-Edisi Kedua (Kedua; C. Yusuf, Ed.). Malang: Literartur Saat.

Guthrie, D. (2000). 1 dan 2 Timotius. In Tafsiran Alkitab Masa Kini Matius-Wahyu Jilid 3 (pp. 1-981). Jakarta: Bina Kasih/OMF.

Handayani, D. M. (2019). Korupsi: Studi Perbandingan Berdasarkan Dunia Timur Tengah Kuno Dan Perjanjian Lama. Pengarah: Jurnal Teologi Kristen, $1(1), 1-8$.

Hasibuan, P. A. S. (2017). Punahnya Etika Moral Elit Politik di Indonesia. MAP (Jurnal Manajemen Dan Adminitrasi Publik, 1(4), 1-10.

Hetharia, H. H. (2012). Korupsi dalam Perspektif Etika Kristen. Tifa Teologi: Jurnal Program Pasca Sarjana Teologi UKI Maluku, 2(2), 1-24.

Kaparang, V., \& Siburian, T. (2021). Refleksi Apologetika Etus pada Isu Suap di Kalangan Orang Kristen. Stullos, 19(1), 32-64.

KPK. (2017). Kisah Korupsi Kita: Anatomi Kasus-Kasus Besar dalam Kajian Interdisipliner. Jakarta: Komisi Pemberantasan Korupsi.

Kramer, A. T. (2004). Singa Telah Mengaum: Para Nabi dalam Perjanjian Lama. Jakarta: Gunung Mulia.

Lembang, A. (2020). Karakter Kepemimpinan Kaleb Bagi Nilai Anti Korupsi 
Aparatur Sipil Negara. Kinaa: Jurnal Kepemimpinan Kristen Dan Pemberdayaan Jemaat, 1(1), 16-26.

Magnis-Suseno, F. (2006). Eika Dasar: Masalah-Masalah Pokok Filsafat Moral. Yogyakarta: Kanisius.

Merrill, E. H. (1985). 1 Samuel. In The Bible Knowledge Commentary (pp. 1-1592). Wheatin, Illinois: Victor Books.

Miller, S. (2016). Corruption and Anti-Corruption ini Policing-Philosophy and Ethical Isssues. In Journal of Business Ethics (Vol. 28). Camberra: Charles Sturt University.

Nasir, M. (2014). Metode Penelitian (10th ed.). Jakarta: Ghalia Indonesia.

Nggebu, S. (2007). Dari Ur-Kasdim Sampai Ke Babel: Karakter 30 Tokoh Perjanjian Lama (B. Simanjuntak \& R. Sutedja, Eds.). Bandung: Kalam Hidup.

Rifai, R. (2018). Mengajarkan Sikap Anti Korupsi Sejak Dini Melalui Refleksi Keluaran 23:1-13. Kurios: Jurnal Teologi Dan Pendidikan Agama Kristen, 4(1), 1. https:// doi.org/10.30995/kur.v4i1.30

Semma, M. (2008). Negara dan Korupsi. Jakarta: Yayasan Pustaka Obor.

Setiadi, W. (2018). Korupsi di Indonesia (Penyebab, Bahaya, Hambatan dan Upaya Pemberantasan, Serta Regulas). Jurnal Legislasi Indonesia UPN Negeri Jakarta, 15(3), 249-262.

Stibbs, A. M. (2000). Ibrani. In Tafsiran Alkitab Masa Kini 3 Matius-Wahyu (pp. 1753-1810). Jakarta: Bina Kasih/OMF.

Sukmadinata, N. S. (2017). Metode Penelitian Pendidikan. Bandung: Rosda Karya.

Sulistyo, P. D. (2020). Pemiskinan Koruptor Jadi Efek Jera Pidana. KOMPAS, p. 3.

Sunariyanti, S. (2018). Penerapan Etika Kristen dalam Pendidikan Anti Korupsi di Keluarga. SANCTUM DOMINE: JURNAL TEOLOGI, 7(1), 107-120. https:// doi.org/10.46495/sdjt.v7i1.46

Tamawiwy-Karundeng, A. C. (2015). Pentingnya Sumbangsih Etika Kristen Dalam Menanggapi Persoalan Korupsi di Indonesia. In Etika dan Religiusitas Anti-Korupsi Dari Konsep ke Praktek di Indonesia (pp. 75-102). Bassel, Swiss: Globethics.Net Focus.

Tour, P. A. (2002). Korupsi. Jakarta: Hasta Mitra.

Transparancy International. (2006). Buku Panduan: Mencegah Korupsi dalam Pengadaan Barang dan Jasa Publik (A. A. Kustiadi, Ed.). Jakarta: Transparancy International Indonesia.

Turksen, U. (2018). Anti-Bribery and Corruption: Perception, Risks and Practice for UK Bank. In N. Ryder (Ed.), White Collar Crime and Risk_Financial Crime, Corruption and the Financial Crisis (pp. 43-91). Bristol: Palgrave Macmillan.

Waluyo, B. (2014). Optimalisasi Pemberantasan Korupsi di Indonesia. Jurnal 
Yuridis, 1(2), 169-182.

Wheaton, D. H. (2000). 1 Petrus. In Tafsiran Alkitab Masa Kini. Jakarta: Bina Kasih/OMF.

Yudha Maulana. (2017, November 27). Jejak Korupsi Tiga Wali Kota Cimahi dari Itoc, Atty dan Ajay $\mathrm{M}$ Priatna. Detik News. Retrieved from https:// news.detik.com/berita-jawa-barat/d-5272187/jejak-korupsi-tigawali-kota-cimahi-dari-itoc-atty-dan-ajay-m-priatna 